\title{
NEED FOR PRESERVATION OF THE GULL LAKE WETLANDS, MANITOBA
}

BUD EWACHA, Native Orchid Conservation Inc., 35 St.Michael Road, Winnipeg, MB R2M 2K7

In June 1998, Native Orchid Conservation Inc. applied for, and received, a grant from Manitoba Hydro to make a botanical survey of the Gull Lake wetlands, to be completed in the year 2000. Our recently completed interim report contains all the information compiled to date concerning the native flora of this wetlands, together with recommendations for their ongoing management. Because the findings thus far are so interesting, we decided to publish this summary of the interim results and recommendations. (The original report to Manitoba Hydro with a complete list of all plant species is available from Native Orchid Conservation Inc.)

The Gull Lake Wetlands, $50^{\circ} 25^{\prime}$ North, $96^{\circ} 31^{\prime}$ 'West, near the southeast corner of Lake Winnipeg, Manitoba, is immediately north of the Brokenhead First Nations Reserve. A very unusual area, it was formerly known as the Scanterbury Bog. Scanterbury was a tiny siding on the railroad between East Selkirk and Beaconia (where the railroad turns east to Stead and then north to Pine Falls). The southern portion of the fens was bisected by Highway 59; the main remaining fens are just west of Highway 59, north of its junction with secondary highway 219 to Stead. Dr. Karen Johnson, curator of Botany at the Museum of Man and Nature has said that these fens have more rare and unusual plants including rare orchids and carnivorous plants than any other known site in Manitoba.

The Gull Lake Wetlands is a topographically confined raised bog, with some central ponds and marginal wet troughs (flarks) and a marginal fen. Section 34, Township 26, Range 7, comprises the biggest part of the fen and is the most interesting from a botanical perspective. $A$ fen is a kind of peatland characterized by a high water table, but with slow internal drainage by seepage down very gradual slopes. The slow moving ground water is enriched by nutrients from upslope materials and thus fens are more mineral rich and less acidic than bogs. The $\mathrm{pH}$ of the groundwater in this fen is approximately 7.0 to 7.5 . The vegetation has a high proportion of sedges along with many other rare and interesting plants.

Once there were hundreds of ponds but now, since the construction of Highway 59 through the area, only about $15 \%$ of the ponds have water in them. Some of the feeding streams were cut off but ten different ones are still active; two of them still keep some of the ponds supplied with water. Also, use of a well in the nearby gravel pit may have damaged some of these streams by drawing down the water table. There are two locations with indications that streams were once present, with one of them actually having water coming out of it at present. A more thorough investigation still needs to be done of the mechanisms that keep this fen supplied with water.

I have collected 255 plant species in the wetlands to date, including 28 species of native orchids, with two new species found this year. One is the Moccasin Flower, and the other is the 
Rose Pogonia which is considered rare in Manitoba. As well, eight species of carnivorous plants, including the rare Oblong-leaved Sundew, Horned Bladderwort, and Linear- leaved
Sundew occur there. Twenty-four species of rare plants have been discovered in this fen, thus far. One of these, the Bog Adder's Mouth Orchid, is rare in Canada (See following lists.)

\section{Provincially And Nationally Rare Vascular Plants}

Arethusa bulbosa L.

Calopogon tuberosus (L.) BSP var tuberosus

Carex capillaris L.

Carex gracillima Schw.

Carex sterilis Willd.

Ceanothus herbaceus Raf.

Chara spp.

Cladium mariscoides (Muhl.) Torr.

Cypripedium arietinum R. Brown

Drosera anglica Huds.

Drosera linearis Goldie

Goodyera tesselata Lodd.

Malaxis monophylla L. var brachypoda

Malaxis paludosa (L.) Sw.

Malaxis unifolia Michx

Platanthera hookeri (Torr.) Lindl.

Pogonia ophioglossoides (L.) Ker

Potentilla gracilis Dougl.

Primula egaliksensis Wormsk.

Pyrola rotundifolia $\mathrm{L}$.

Rhynchospora alba (L.) Vahl

Rhynchospora capillacea Torr.

Solidago uliginosa Nutt. (S.Purshii Porter)

Utricularia cornuta Michx.

* rare in Canada
Dragon's Mouth

Grass Pink

Hair-like Sedge

Slender Sedge

Dioecious Sedge

New Jersey Tea

Stonewort (a kind of algae)

Twig Rush

Ram's Head Lady's-Slipper

Oblong-leaved Sundew

Slender-leaved Sundew

Tesselated Rattlesnake Plantain

White Adder's-Mouth

Bog Adder's-Mouth *

Green Adder's-Mouth

Hooker's Orchid

Rose Pogonia

Graceful Cinquefoil

Greenland Primrose

Common Wintergreen

White Beak Rush

Slender Beak Rush

Bog Goldenrod

Horned Bladderwort

\section{Index Of Gull Lake Orchid Species}

Amerorchis rotundifolia (Pursh) Huttén

Arethusa bulbosa L.

Calopogon tuberosus (L.) BSP. var. tuberosus

Calypso bulbosa (L.) Oakes var. americana (R.Brown) Coeloglossum viride (L.) Hartmann

Corallorhiza maculata Raf.

Corallorhiza striata Lindl.

Corallorhiza trifida Chat.

Cypripedium acaule Ait.

Cypripedium arietinum R. Brown

Cypripedium calceolus L. var. parviflorum (Salisb.) Fem.

Cypripedium calceolus L. var. pubescens (Willd.) Correll

Cypripedium reginae (Walt)

Goodyera repens (L.) R.Br. var. ophiodes Fern.
Small Round-leaved Orchid

Dragon's mouth

Grass Pink

Luer Fairy or Venus Slipper

Long-bracted Orchid

Spotted Coralroot

Striped Coralroot

Northern or Early Coralroot

Moccasin Flower

Ram's Head Lady's-Slipper

Small Yellow Lady's-Slipper

Large Yellow Lady's-Slipper

Showy Lady's-Slipper

Lesser Rattlesnake Plantain 
Goodyera tesselata Lodd.

Liparis loeselli (L.) Richard

Listera cordata (L.) R. Brown

Malaxis monophylla L. var. brachypoda

Malaxis paludosa (L.) Sw.

Malaxis unifolia Michx.

Platanthera dilatata (Pursh) Lindl. ex Beck

Platanthera hookeri (Torr) Lindl.

Platanthera hyperborea (L.) Lindl

Platanthera obtusata (Pursh) Lindl(L) R. Br.

Platanthera orbiculata Torr. Lindl

Pogonia ophioglossoides ( $\mathrm{L}>$ ) Ker

Spiranthes lacera Raf.

Spiranthes romanzoffiana Cham.

\section{Recommendations}

Based on observations that we have made during this plant survey of this very special area, and in view of the very high concentration of rare plants, we recommend:

1. All plans to pump water from this bog to maintain water levels in the small, nearby resort lake, Gull Lake, of only 258 acres (105 ha), but with 300 summer cottage lots and 26 permanent residents, would further disturb the hydrology and would almost certainly have a negative effect on the rare native flora. Any such plans should be shelved until a detailed plant survey is completed.

2. Following this, any decisions about the area's future should be made only after consulting people who have extensive experience working with wetland ecosystems. The Brokenhead First Nation, because of their close proximity and traditional use of the area, should also be consulted regarding any future development plans.

3. Consideration should be given to having the fens set aside as a special park where further field studies could be done, the plants protected, and a
Tesselated Rattlesnake Plantain Loesel's Twayblade Heart-leaved Twayblade White Adder's-mouth Bog Adder's-mouth Green Adder's-mouth Tall Leafy White Orchid Hooker's Orchid Tall Leafy Green Orchid Blunt-leaf Orchid Large Round-leaf Orchid Rose Pogonia

Slender Ladies'-tresses Hooded Ladies'-tresses

method of controlled access be set up. This rare and beautiful ecosystem should be preserved for future generations to enjoy.

\section{Acknowledgements}

I would like to thank everyone who helped me with this survey and the completion of this report. Special thanks to Dr.Karen Johnson, Laura Reeves, Gloria Keleher and Gerry Oliver for their generosity in lending their professional expertise to this project. I am grateful to Dr. Johnson for her comments and suggestions. Dr. Vernon L. Harms provided constructive criticism. Any errors in this report are strictly the responsibility of the author.

\section{Bibliography}

1. JOHNSON, KAREN L. 1986 Rare plant alert! An orchid list for Manitoba. Bull.Man. Naturalists Soc. 11(9):13.

\section{PETRIE ,W. 1981 Guide to orchids of} North America. Hancock House, Vancouver.

3. WHITE, D.J. and KAREN L. JOHNSON . 1980. The rare vascular plants of Manitoba. Syllogeus 27. Nat. Museums of Canada, Ottawa. 